\title{
Erratum: TMEM140 is associated with the prognosis of glioma by promoting cell viability and invasion

Bin $\mathrm{Li}^{1 \dagger}$, Ming-Zhu Huang ${ }^{2 \dagger}$, Xiao-Qiang Wang ${ }^{1 *}$, Bang-Bao Tao ${ }^{1}$, Jun Zhong ${ }^{1}$, Xu-Hui Wang ${ }^{1}$, Wen-Chuan Zhang ${ }^{1}$ and Shi-Ting $\mathrm{Li}^{1^{*}}$

It has been brought to our attention that in Fig. two of the article [1], the immunoblots in the middle panel were incorrectly labeled as TREM2 instead of TMEM140. The correct figure is included below (Fig. 1), in which the immunoblots in the middle panel are labeled as TMEM140. This labeling correction does not affect the results or interpretation of the results. We apologize for this error.

\footnotetext{
Author details

'Department of Neurosurgery, Xinhua Hospital, Shanghai Jiaotong University School of Medicine, Shanghai 200092, China. ${ }^{2}$ Department of Oncology,

Fudan University Shanghai Cancer Center, Shanghai 200032, China.
}

Received: 6 August 2015 Accepted: 14 August 2015

Published online: 02 September 2015

\section{Reference}

1. Li B, Huang MZ, Wang XQ, Tao BB, Zhong J, Wang XH, et al. TMEM140 is associated with the prognosis of glioma by promoting cell viability and invasion. J Hematol Oncol. 2015;8(1):89. doi:10.1186/s13045-015-0187-4.

*Correspondence: wangxq10@126.com; lishiting12@126.com

${ }^{\dagger}$ Equal contributors

'Department of Neurosurgery, Xinhua Hospital, Shanghai Jiaotong University School of Medicine, Shanghai 200092, China

Full list of author information is available at the end of the article
Submit your next manuscript to BioMed Central and take full advantage of:

- Convenient online submission

- Thorough peer review

- No space constraints or color figure charges

- Immediate publication on acceptance

- Inclusion in PubMed, CAS, Scopus and Google Scholar

- Research which is freely available for redistribution 


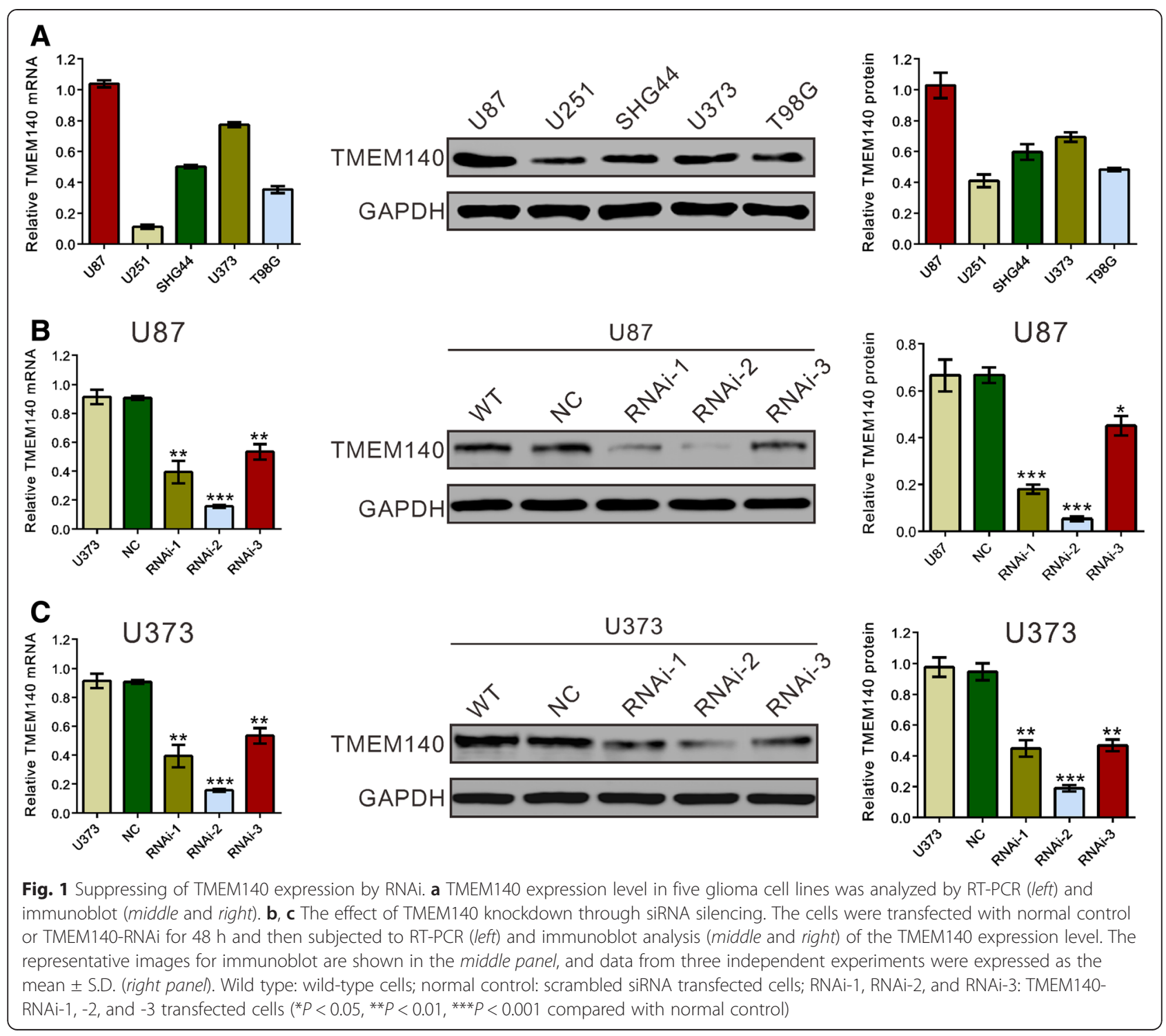

